\title{
Особенности энергетической структуры и оптических свойств квантовых точек сульфида кадмия, синтезированных с помощью технологии Ленгмюра-Блоджетт
}

\author{
К.А. Свит ${ }^{1}$, А.А. Зарубанов ${ }^{1}$, К.С. Журавлев ${ }^{1,2}$ \\ ${ }^{1}$ Институт физики полупроводников им. А.В. Ржанова СО РАН, Новосибирск, \\ 630090, пр. Лаврентиева, 13 \\ тел:+7 (923-141-2731), эл. nочта: svitkirill1989@gmail.com
}

DOI 10.34077/RCSP2021-125

Квантовые точки (КТ) из полупроводниковых материалов группы $\mathrm{A}_{2} \mathrm{~B}_{6}$ в настоящее время уже нашли практическое применение в дисплеях, где они используются как в качестве активного светоизлучающего элемента, так и в виде люминофора. Однако, дальнейшее развитие технологии на основе КТ требует повышения значения квантового выхода приборов на их основе. Для получения высокого квантового выхода важнейшим элементом является понимание энергетической структуры КТ, которая определяется материалом и геометрией КТ точки, кристаллической структурой, а также состоянием ее поверхности.

В данной работе исследовались оптические свойства CdS KT, сформированных в матрице пленки Ленгмюра-Блоджетт с последующим отжигом матрицы в атмосфере аммиака. С целью определения энергетического спектра КТ и установления влияния на него состояния поверхности КТ в данной работе была исследована нестационарная ФЛ КТ CdS в диапазоне температур 5-300 К.

Кинетика ФЛ описывается суммой двух экспонент во всем диапазоне температур. Величины времен жизни обеих компонент зависят от температуры и варьируются от 40 до 100 нсек для быстрой компоненты и от 150 до 450 нсек для медленной. Обнаруженные величины превышают более чем на порядок теоретическое время жизни экситона в КТ

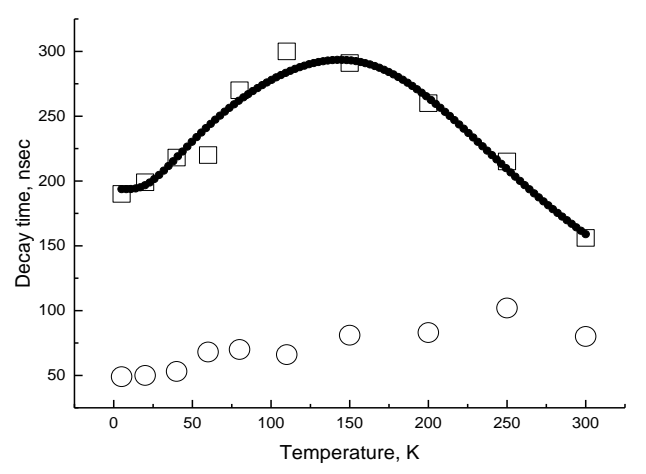

Рис. 1. Температурная зависимость времен затухания ФЛ CdS KT. Квадраты медленное время жизни, круги - быстрое время жизни, сплошная линия аппроксимация трехуровненвой моделью [1]. $\mathrm{CdS}$, что свидетельствует о рекомбинации через локализованные состояния. Стоксов сдвиг между спектрами ФЛ и поглощения составляет 150 мэВ, что также не может быть объяснено с точки зрения тонкой структуры экситона и указывает на рекомбинацию через уровни ловушек. Полученные данные свидетельствуют о наличии в энергетическом спектре КТ близких по энергии уровней ловушек уровней ловушек для дырок с глубиной залегания $\Delta \mathrm{E} \sim 100$ мэВ. В связи с тем, что КТ пассивированы аммиаком, который насыщает оборванные связи атомов кадмия, предложено, что ловушки могут быть обусловлены наличием недокоординированных атомов серы на поверхности КТ. Из температурной зависимости времени жизни установлена структура валентной зоны КT CdS. Установлено, что основное состояние дырок имеет $1 \mathrm{P}$ симметрию и совместно с основным $1 \mathrm{~S}$ состоянием электрона образует темное состояние экситона.

\section{Лumepamypa}

[1] L. Zhaojun et al., Light Sci. Appl. 9, 83 (2020)

[2] S. A. Crooker, T. Barrick, J. A. Hollingsworth, and V. I. Klimov, Appl. Phys. Lett. 82, 2793 (2003). 